\title{
Heterosexual transmission of hepatitis B and implications for vaccine prevention strategies
}

MIRIAM J ALTER, PHD

\begin{abstract}
MJ ALTER. Heterosexual transmission of hepatitis B and implications for vaccine prevention strategies. Can J Infect Dis 1991;2(Suppl A):13A-17A. Since 1985, cases of hepatitis $\mathrm{B}$ virus infection attributable to heterosexual activity have increased by $38 \%$, whereas those attributable to homosexual activity have declined by $62 \%$. Heterosexual activity now accounts for $26 \%$ of cases and has replaced homosexual activity in importance as a risk factor for hepatitis B. For heterosexuals, the number of recent (ie, in the preceding four to six months) and lifetime sex partners, as well as a history of other sexually transmitted diseases (eg, syphilis) appear to be significantly associated with increased hepatitis B virus infection. Of equal concern is the rising number of cases among parenteral drug users in the United States and some minority groups, including blacks, Hispanics and Asians. Hepatitis B prevention by administering hepatitis $B$ vaccine to high risk groups before exposure to infection has not been successful, and at least $30 \%$ of hepatitis B cases in the United States have no identifiable risk factors. Thus, participation in the current programs which target only high risk groups is not possible. The ideal immunization strategy is integration of hepatitis B vaccine into the routine childhood immunization schedule.
\end{abstract}

Key Words: Hepatitis B, Immunization, Sexually transmitted diseases

\section{La fransmission hétérosexuelle de l'hépatite B et les conséquences pour les stratégies de vaccination préventive}

RESUME: Depuis 1985, les cas d'hépatite B attribuables aux contacts hétérosexuels ont augmenté de $38 \%$ tandis que ceux qui résultent de pratiques homosexuelles ont diminué de $62 \%$. Les rapports hétérosexuels expliquent présentement $26 \%$ des cas; ils ont remplacé l'activité homosexuelle en tant que facteur de risque important de l'hépatite B. Parmi les hétérosexuels, le nombre de partenaires récents (c.-à-d. au cours des 4 à 6 mois précédents) et permanents, ainsi que les antécédents d'autres MTS (syphilis, par exemple), semblent présenter un lien significatif avec l'augmentation des risques d'infection par le virus de l'hépatite B (HBV). Aux États-Unis, tout aussi préoccupant est le nombre grandissant de cas notés parmi les toxicomanes par voie parentérale et dans certains groupes minoritaires - Noirs, Hispaniques et Asiatiques, notamment. Les campagnes de vaccination anti-hépatite B visant les groupes à haut risque n'ont pas donné les résultats escomptés, $30 \%$ au moins des adultes américains infectés ne présentant pas de facteur de risque identifiable. La stratégie idéale d'immunisation consiste à intégrer le vaccin anti-hépatite $\mathrm{B}$ aux programmes de vaccinations de routine destinés aux enfants.

Hepatitis Branch, Division of Viral and Kickettsial Diseases, Center for Infectious Diseases. Centers for Disease Control. Public Health Service, Department of Health and Human Services. Atlanta. Georgia. USA

Correspondence and reprints: Dr MJ Alter. Hepatitis Branch, Building 6, Room 154(A-33). 1600 Clifton Road, Atlanta. GA 30333. USA 
W ORLDWIDE, CHRONIC HEPATITIS B VIRUS INFECtion is a major cause of chronic hepatitis, cirrhosis and primary hepatocellular carcinoma (1). In countries with low rates of infection, transmission during infancy and childhood is uncommon and the majority of cases occur in young adults as a result of behavioral, lifestyle or occupational exposures. In the United States, reported rates of hepatitis B have increased more than $60 \%$ during the past decade.

As with most diseases, viral hepatitis is significantly underreported. Estimates of the annual number of hepatitis B virus infections, adjusted for disease underreporting and asymptomatic infections, indicate that from 1979 to $1989,200,000$ to 300,000 cases of hepatitis B virus infection occurred annually (2). Sexual activity, both homosexual and heterosexual, is the most commonly reported risk factor for hepatitis B virus infection. Since 1985, however, the number of cases of hepatitis $\mathrm{B}$ in homosexual men has declined by $62 \%$; in contrast, the number of cases of hepatitis $B$ due to heterosexual activity has increased by $38 \%$ (3). Heterosexual activity now accounts for $26 \%$ of cases (Figure 1) and has replaced homosexual activity in importance as a risk factor for hepatitis B.

\section{SHIFT IN HOMOSEXUAL TO HETEROSEXUAL TRANSMISSION}

Historically, homosexual men have been one of the highest risk groups for hepatitis B virus infection and were responsible for $20 \%$ of cases of hepatitis B from 1980 to 1985 (3). Infection in this risk group has been associated with receptive anal intercourse, multiple sexual partners, and number of years of sexual activity such that after five years of sexual activity $70 \%$ of men were infected (4). The number and proportion of cases of hepatitis $B$ attributable to homosexual activity have declined dramatically in recent years (3). This change in the epidemiology of hepatitis B virus infection among homosexual men is probably due to changes in high risk sexual behaviour to lessen the risk of human immunodeficiency virus (HIV) infection; few individuals in this risk group have received hepatitis $B$ vaccine because of a lack of programs.

Unfortunately, the number of cases of hepatitis $B$ attributable to heterosexual activity has increased since 1985. Some of the same factors associated with an increased risk of hepatitis B virus infection in homosexual men, ie, multiple partners, number of years of sexual activity, and history of other sexually transmitted diseases, have been found to be associated with an in- creased risk of hepatitis $\mathrm{B}$ virus infection in heterosexual men and women.

\section{NUMBER OF SEXUAL PARTNERS}

Two studies have found an association between hepatitis $B$ virus infection and the number of recent sexual partners. One of these found that heterosexual women attending a clinic for sexually transmitted diseases (STDs) who had a history of three or more partners in the preceding six month period were more likely to have evidence of hepatitis $\mathrm{B}$ virus infection (18\%) than women with fewer than three partners (1\%) (5). No such association was found for heterosexual men, and other risk factors associated with hepatitis B virus infection were not documented.

For white men and women attending an STD clinic in the United States who had no history of other risk factors for hepatitis B, increasing numbers of recent (ie, within the preceding four months) partners were associated with a fourfold risk of hepatitis B virus infection (6). In this same study, a group of white students attending a large coeducational university and accessed during a school-wide blood donor clinic had an overall prevalence of hepatitis B virus infection of only $2 \%$. Students with three or more partners in the preceding four months, however, had a prevalence of $14 \%, 11$-fold higher than students with fewer than three partners. Among persons with acute hepatitis $\mathrm{B}$ and no other commonly recognized exposures, two case control studies have demonstrated that having recent multiple heterosexual partners is significantly associated with acquiring acute disease (7, unpublished data).

The number of lifetime sexual partners has also been associated with hepatitis B virus infection. Studies conducted in heterosexual men and women attending STD clinics have found a direct relationship between increasing number of life-

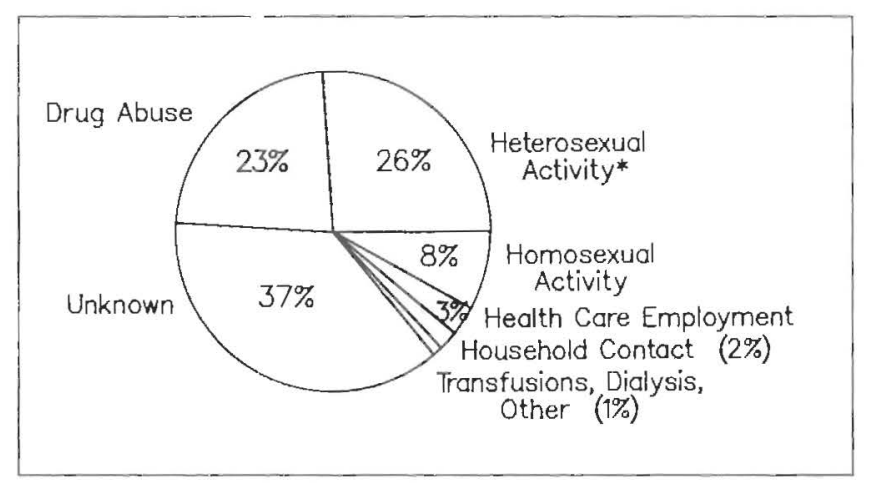

Figure 1) Risk factors associated with reporled cases of hepatitis B. United States, 1989. *Includes sexual contact with acute cases, carriers and multiple partners. (Source: Centers for Disease Control sentinel counties) 
time partners and increasing risk of hepatitis B virus infection, reaching $20 \%$ to $30 \%$ in those with the greatest number of partners $(6,8)$. Number of lifetime partners has also been associated with an increased risk of hepatitis B virus infection among university students who had no other risk factors for hepatitis B (6). In this group, the prevalence of hepatitis B virus infection was $7 \%$ in students with 10 or more lifetime partners compared with $2 \%$ in those with fewer than 10 partners. These studies also found an association between hepatitis B virus infection and history of other STDs.

The results of two population-based studies conducted in the United States are of particular interest in assessing the role of sexual activity in the transmission of hepatitis $\mathrm{B}$ virus between heterosexuals. One of these was a seroepidemiological survey of a random sample of households in Belle Glade, Florida, which provided the opportunity to evaluate risk factors for hepatitis B virus in a racially mixed community (9). The overall prevalence of hepatitis B virus infection was $26 \%$, higher than the $5 \%$ reported in the United States general population. As few persons were found to have other risk factors for hepatitis B virus infection such as homosexual activity and parenteral drug use, these factors were excluded from the analysis. Risk factors found to be associated with hepatitis $\mathrm{B}$ virus infection among the adults in this community were a positive test for syphilis and two or more lifetime sexual partners, each of which was associated with a two- to threefold increased risk in both men and women. The second study reported results from a serological survey of a probability sample of the United States population (National Health and Nutrition Examination Survey II) conducted between 1976 and 1980 (10). The prevalence of hepatitis B virus infection among blacks was almost five times higher than among whites ( $14 \%$ versus $3 \%$ ), and both black race and seropositivity for syphilis were found to be independently associated with hepatitis B virus seropositivity. Data on number of sexual partners were not obtained.

\section{PARENTERAL DRUG USE}

Of equal concern is the increasing number of cases of hepatitis B associated with parenteral drug use. Similar increases have been observed in cases of hepatitis A and non-A,non-B hepatitis, suggesting that hepatitis associated with parenteral drug use is a widespread problem $(11,12)$. In addition, outbreaks of delta hepatitis, an infection which significantly increases the severity of both acute and chronic hepatitis $B$, have been largely associated with parenteral drug users in the United States (13).
Adults in general and groups such as parenteral drug users in particular have been extremely difficult to reach for delivery of vaccine. One such program designed to provide hepatitis B vaccine free of charge to susceptible drug users and their sexual partners (14) found that of the drug users screened at a variety of community access sites, $54 \%$ had been injecting drugs for at least five years. Of the long term drug users, 95\% had evidence of previous hepatitis B virus infection and overall only $24 \%$ of the drug users who were accessed during the program were susceptible to hepatitis $B$ virus infection and therefore candidates for vaccination. Factors associated with susceptibility included young age (less than 25 years old), fewer than two years of drug use, infrequent drug use (less than once a month), and no history of incarceration. In addition, only $39 \%$ of those susceptible received at least two doses of vaccine over a six month period of intensive followup. In contrast, sexual partners of drug users were less likely to have serological evidence of infection (79\% were susceptible) and were more likely to receive at least two doses of vaccine (54\%).

\section{OTHER FACTORS}

An important feature of the epidemiology of hepatitis B in the United States is that at least $30 \%$ of patients cannot be associated with an identifiable risk factor, thus placing them out of reach of the current immunization strategy that targets only high risk groups. These patients tend to belong to minority populations and have characteristics associated with a low socioeconomic level $(3,7)$. In the United States, minority populations are disproportionately affected by viral hepatitis. Rates of acute hepatitis B are approximately two times higher in blacks, Hispanics and other racial/ethnic groups, compared with whites (3). Among some of these minority groups, the incidence of reported cases has increased 60\% to $100 \%$ over the past few years. The prevalence of chronic hepatitis $\mathrm{B}$ virus infection is five to 30 times higher in blacks and Asians compared with whites. Furthermore, rates of primary liver cancer in blacks and Asians are, respectively, 1.5 and 4.2 times the rate for whites.

Ninety per cent of the cases of hepatitis B reported in the United States are in adults, whereas $9 \%$ are in adolescents aged 11 to 19 years. Most health care providers probably overlook this age group when considering persons at risk of infection. Of the cases of hepatitis B in adolescents with a known source of infection, $50 \%$ can be attributed to sexual or other person-to-person contact and $47 \%$ to parenteral drug use. Sexual transmission or person-to-person contact ac- 
counts for an almost equal number of infections among adolescent males and females. In adults, however, this risk factor accounts for almost twice as many infections in females as in males. Although parenteral drug use and male homosexual activity account for approximately the same proportion of infections in adolescents as in adults, $60 \%$ of adolescents have no known source of infection compared with $30 \%$ of adults.

The importance of sexual transmission of hepatitis $B$ virus among adolescents is further suggested by the findings of a serological survey of a population-based sample of whites and blacks in the United States conducted from 1976 to 1980 (10). The prevalence of hepatitis B virus infection began to increase by age 12 years among blacks and by age 15 years among whites, with blacks having a prevalence three to six times higher than whites in the same age range. The risk of infection was associated with a positive serological test for syphilis.

\section{PREVENTION OF HEPATITIS B}

Prevention of hepatitis B is easily accomplished through the administration of hepatitis $B$ vaccine before exposure to infection. Hepatitis B vaccine, however, has not been widely used for the prevention of sexually transmitted hepatitis B virus infection, despite longstanding recommendations for immunization of homosexually active men. persons with multiple sexual partners, or those with multiple episodes of STDs (2). Among many reasons for the lack of hepatitis $B$ vaccine use, the most important appears to be a lack of knowledge on the part of patients and health care providers that hepatitis B is an STD and can be acquired by heterosexual activity. A study done in 1985 to determine the knowledge and practices of physicians in the prevention of hepatitis B showed that $45 \%$ knew that homosexual activity was a risk factor for hepatitis B virus infection or that sexual contacts of patients with hepatitis $\mathrm{B}$ were at risk of infection, whereas only $10 \%$ were aware that heterosexual activity with multiple partners was a risk factor (unpublished data).

Most members of high risk populations are not aware of their risk or do not become aware until they are infected, making control of the disease very difficult. In addition, approximately $30 \%$ of patients with hepatitis $B$ have no identifiable source of infection, making them unable to respond to strategies that target only high risk groups. The only group in which there has been a significant change in disease rates as a result of immunization comprises persons at risk through occupational exposure (3). The risk of occupationally acquired hepatitis $B$ virus infection has been well recognized and associated with exposure to blood or potentially infectious body fluids that are contaminated with blood $(15,16)$. Although the majority of persons receiving hepatitis $B$ vaccine in the United States are at risk of infection through occupational exposure, this group accounted for no more than $5 \%$ of cases even before the vaccine was introduced.

Since the current immunization strategy (ie, targeting high risk groups) has failed to have a significant impact on disease incidence, a re-evaluation of this approach is underway in the United States. The feasibility of immunizing a significant proportion of persons with multiple heterosexual partners or parenteral drug users before these populations become infected with hepatitis $B$ virus must be questioned. The ideal immunization strategy to accomplish such a goal involves immunization of infants and adolescents. This strategy would lead to disease prevention by providing immunity from infection before persons engage in risk behaviour and could preclude infections in persons who have no known risk factors. The Immunization Practices Advisory Committee of the United States Public Health Service has recently voted to recommend the integration of hepatitis B vaccine into the routine childhood immunization schedule. When the resources to implement such a program become available, the control of hepatitis $B$ virus infection will become a reality.

\section{REFERENCES}

1. Maynard JE, Kane MA, Alter MJ, et al. Control of hepatitis B by immunization: Global perspectives. In: Zuckerman AJ, ed. Viral Hepatitis and Liver Disease. New York: Alan R Liss Inc, 1988:967-9.

2. Centers for Disease Control. Protection against viral hepatitis: Recommendations of the Immunization Practices Advisory Committee (ACIP). MMWR 1990;39.

3. Alter MJ, Hadler SC, Margolis HS, et al. The changing epidemiology of hepatitis B in the United States: Need for alternative vaccination strategies. JAMA 1990:263:1218-22.

4. Schreeder MT, Thompson SE, Hadler SC, et al. Hepatitis B in homosexual men: Prevalence of infection and factors related to transmission. J Infect Dis 1982;146:7-15.

5. Fulford KWM. Dane DS. Australia antigen and antibody among patients attending a clinic for sexually transmitted diseases. Lancet 1973:i:1470-3.

6. Alter MJ, Ahtone J, Weisfuse I, et al. Hepatitis B virus transmission between heterosexuals. JAMA 1988:256:1307-10.

7. Alter MJ, Coleman PJ, Alexander WJ, et al. Importance of heterosexual activity in the transmission of hepatitis $B$ and non-A, non- $B$ hepatitis. JAMA 1989:262:1201-5. 
8. Baddour LM, Bucak VA, Somes G, et al. Risk factors for hepatitis B virus infection in black female attendees of a sexually transmitted disease clinic. Sex Transm Dis 1988;15:174-6.

9. Rosenblum LS, Hadler SC, Castro KG, et al. Heterosexual transmission of hepatitis $B$ virus in Belle Glade, Florida. J Infect Dis 1990;161:407-11.

10. McQuillan GM, Townsend TR, Fields HA, et al. Seroepidemiology of hepatitis B virus infection in the United States. Am J Med 1989:87 (Suppl 3A):5S-10S.

11. Alter MJ, Hadler SC, Judson FN, et al. Risk factors for acute non-A, non- $B$ hepatitis in the United States and association with hepatitis C virus infection. JAMA 1990:264:2231-5.

12. Shapiro CN, Shaw FE, Mandel EJ, Hadler SC. Epidemiology of hepatitis A in the United States. In: Hollinger FB, Lemon SM, Margolis HS, eds.
Viral Hepatitis and Liver Disease. Baltimore: Williams and Wilkins. (In press)

13. Lettau L, McCarthy JH, Smith MH, et al. An outbreak of severe hepatitis due to delta and hepatitis $B$ viruses in parenteral drug abusers and their contacts. N Engl J Med 1987;317:1256-61.

14. Schatz G, Hadler S, McCarthey J, et al. Outreach to needle users and sexual contacts: A multi-year. community-wide hepatitis $\mathrm{B} /$ delta hepatitis control program in Worcester, Massachusetts. In: Coursaget $\mathrm{P}$, Tong MJ, eds. Progress in Hepatitis $\mathrm{B}$ Immunization. London: John Libbey, 1990.

15. Hadler SC, Doto IL, Maynard JE, et al. Occupational risk of hepatitis B infection in hospital workers. Infect Control 1985;6:24-31.

16. West DJ. The risk of hepatitis B infection among health professionals in the United States: A review. Am J Med Sci 1984:287:26-33. 


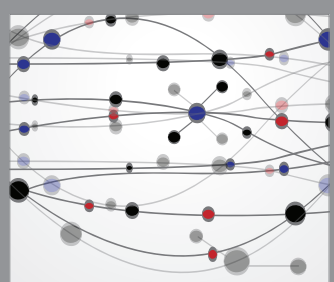

The Scientific World Journal
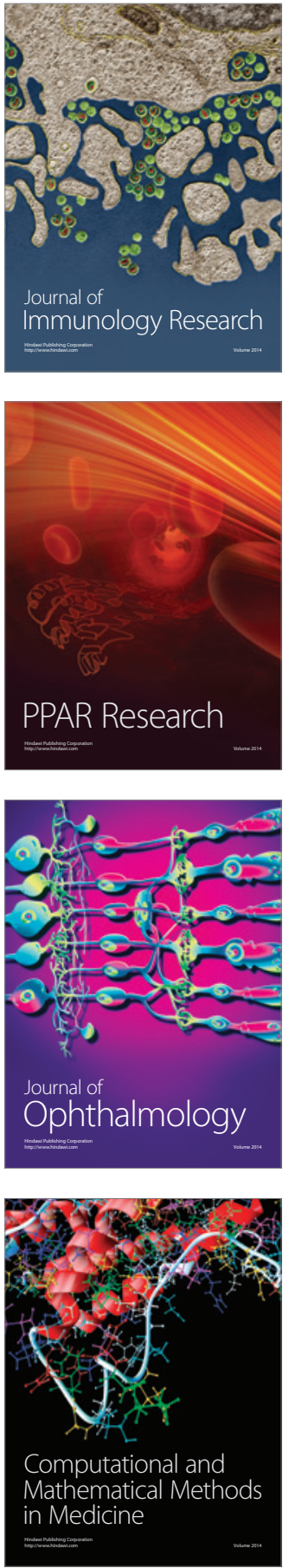

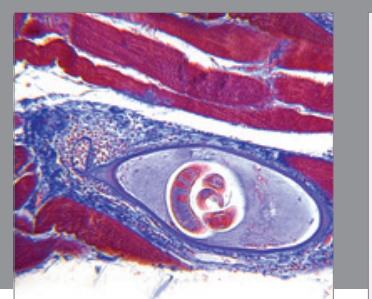

Gastroenterology Research and Practice

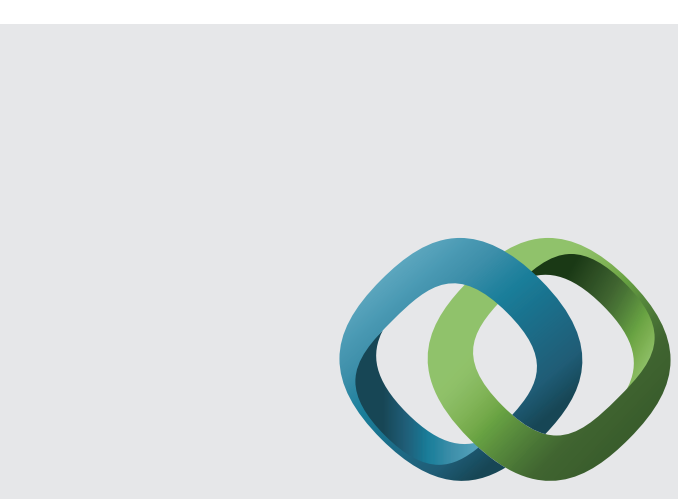

\section{Hindawi}

Submit your manuscripts at

http://www.hindawi.com
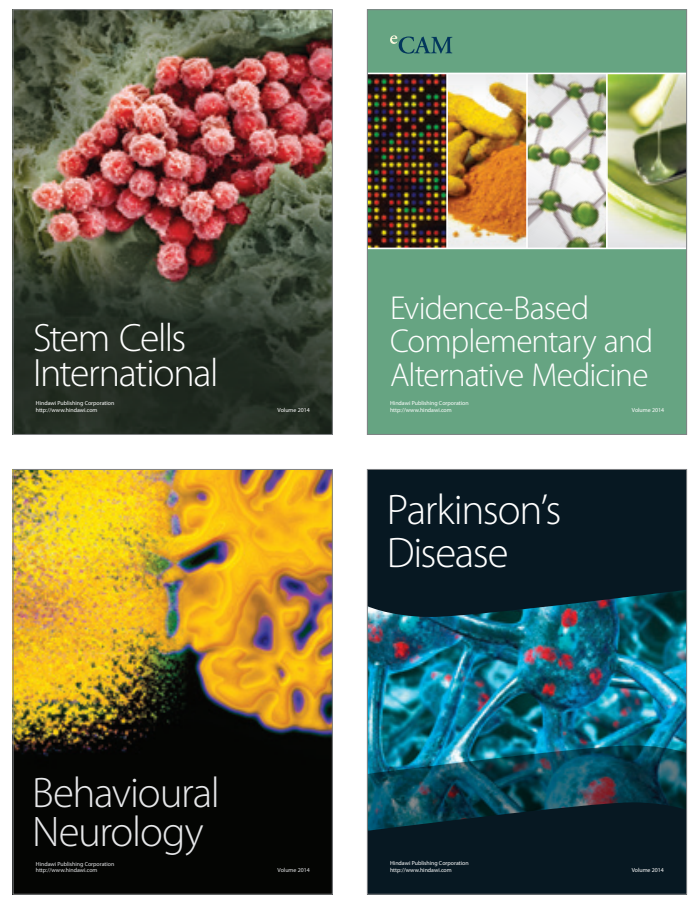
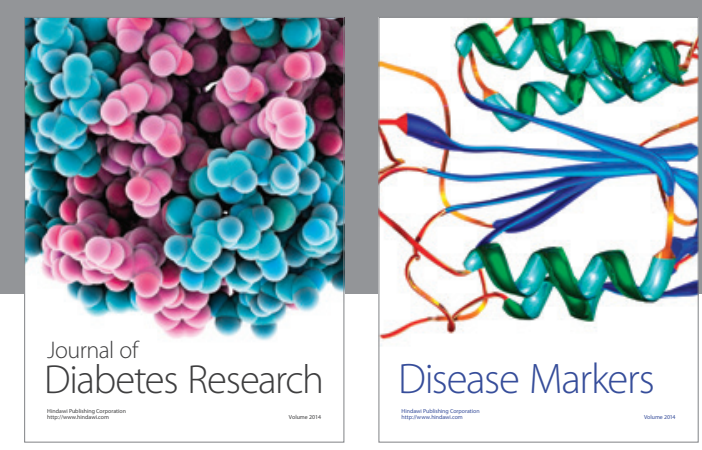

Disease Markers
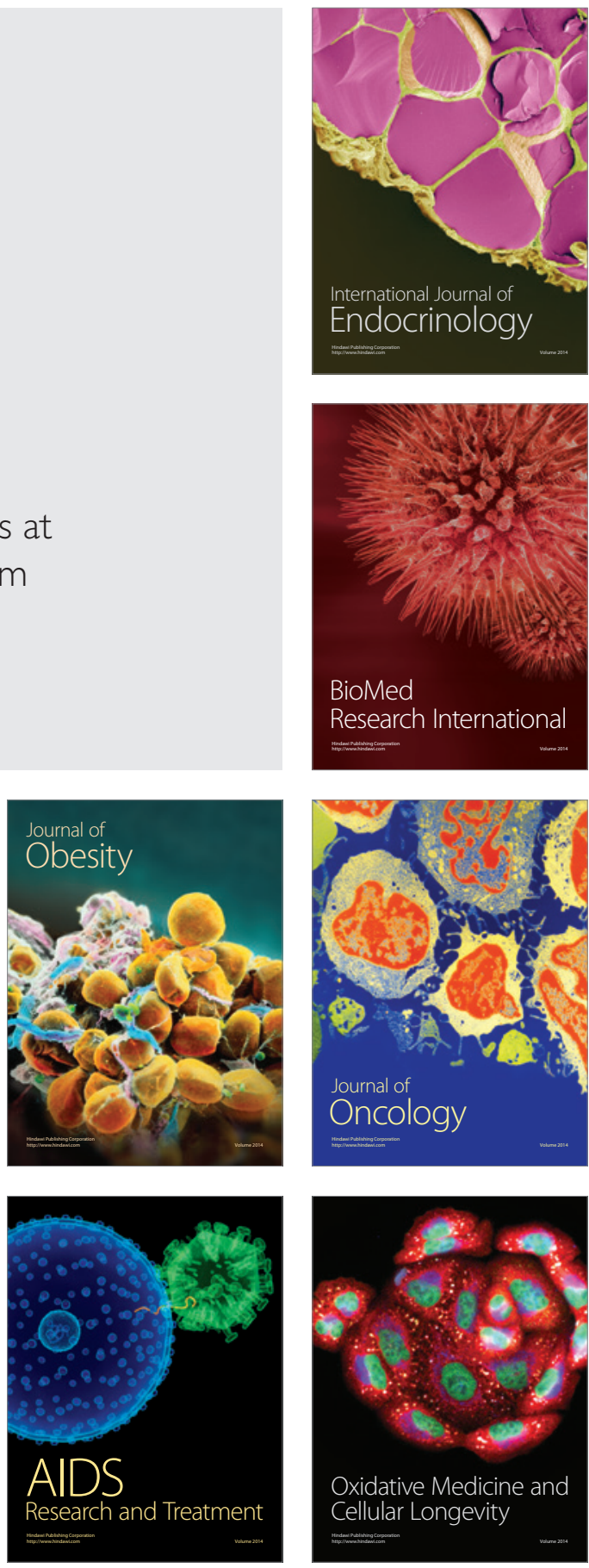